\title{
PENGEMBANGAN KURIKULUM DI INDONESIA \\ DALAM MENGHADAPI TUNTUTAN ABAD KE-21
}

\author{
Diah Rusmala Dewi \\ diahrd95@gmail.com \\ UIN Sunan Kalijaga Yogyakarta
}

\begin{abstract}
This article aims to examine curriculum development in Indonesia in facing the demands of 21st century competencies. The method used in this research is literature study where the author tries to find, compile and analyze various information through various related sources. The rapid development of information and communication technology as well as free competition between countries in all fields has marked the start of the 21st century. This has implications for the world life that students face today is different and much more complex than the previous era. The results of this study are: 21st century curriculum development requires students to learn more and be proactive so that they have 21st century competencies which include: communication, collaboration, critical thinking and problem solving, creativity and innovation skills and mastery of ICT which require higher order thinking skills or Higher Order Thinking Skills (HOTS). The expected positive impact of this article is an increase in the quality of education in Indonesia so as to create an educated society in the future who is able to face the challenges of an increasingly competitive era.
\end{abstract}

Keywords: Development, Curriculum, 21st Century.

\begin{abstract}
Abstrak
Artikel ini bertujuan untuk mengkaji pengembangan kurikulum di Indonesia dalam menghadapi tuntutan kompetensi abad ke-21. Metode yang digunakan dalam penelitian ini yaitu studi pustaka dimana penulis berusaha menemukan, menyusun dan menganalisis berbagai informasi melalui berbagai sumber terkait. Berkembangnya teknologi informasi dan komunikasi yang pesat serta persaingan bebas antar negara di segala bidang telah menandai dimulainya abad 21. Hal tersebut berimplikasi pada kehidupan dunia yang dihadapi peserta didik saat ini berbeda dan jauh lebih kompleks dibanding zaman sebelumnya. Adapun hasil penelitian ini yaitu: pengembangan kurikulum abad 21 menuntut peserta didik untuk belajar lebih banyak dan proaktif agar mereka memiliki kompetensi abad 21 yang mencakup: communication, collaboration, critical thingking and
\end{abstract}


problem solving, creativity and innovation skill serta penguasaan TIK yang membutuhkan keterampilan berpikir tingkat tinggi atau Higher Order Thinking Skill (HOTS). Dampak positif yang diharapkan dari artikel ini ialah adanya peningkatan kualitas pendidikan di Indonesia sehingga tercipta masyarakat terdidik di masa depan yang mampu menghadapi tantangan zaman yang semakin kompetitif.

\section{Kata Kunci : Pengembangan, Kurikulum, Abad 21}

\section{A. Pendahuluan}

Berkembangnya teknologi informasi dan komunikasi yang pesat dalam segala segi kehidupan telah menandai dimulainya abad 21. Melalui perkembangan teknologi, dunia saling terhubung melampaui sekat-sekat geografis sehingga dunia menjadi tanpa batas. Dengan semakin menyempitnya dan meleburnya faktor "ruang dan waktu" menjadi bukti bahwa konteks pemanfaatan teknologi informasi dan komunikasi telah memasuki segala aspek kehidupan manusia yang berdampak pada terjadinya perubahan kualifikasi dan kompetensi sumber daya manusia. Tidak hanya itu, hal tersebut berimplikasi pada berbagai resiko dan ketidakpastian yang harus dihadapi oleh peserta didik dimana kehidupan dunia yang dihadapi peserta didik saat ini berbeda dan jauh lebih kompleks dibanding zaman sebelumnya sehingga hal tersebut menuntut peserta didik untuk belajar lebih banyak dan proaktif terhadap berbagai perubahan agar mampu memepersiapkan diri dalam menghadapi tantangan global.

Dengan demikian, pemerintah Indonesia dalam hal ini terus berupaya untuk meningkatkan aspek pendidikan di setiap jenjang secara berkelanjutan dengan menyesuaikan perkembangan pendidikan dunia. Salah satunya yaitu dengan menerapkan kerangka kerja pembelajaran inovatif abad 21 yang dicetuskan oleh Partnership for 21st Century Learning (2011) dalam pengembangan kurikulumnya. ${ }^{1}$ Sebagaimana pula yang termuat dalam Peraturan Menteri Pendidikan Nasional No. 16 tahun 2007 yaitu menjadikan perkembangan media teknologi informasi sebagai salah satu landasan pokok

1 Badan Standar Nasional Pendidikan, “Paradigma Pendidikan Nasional Di Abad-21” (BSNP, 2010). 
dalam pengembangan kurikulum abad 21. ${ }^{2}$ Hal tersebut berimplikasi pada semua yang terlibat dalam proses pendidikan di sekolah-sekolah Indonesia agar menguasai ICT literacy Skill. Guru, siswa, bahkan orangtua siswa harus melek teknologi dan media komunikasi agar memiliki kesiapan dalam menghadapi tantangan perkembangan pendidikan abad 21.

Selain itu, penguasaan kompetensi-kompetensi abad 21 oleh pendidik dan peserta didik diharapkan dapat dipersiapkan melalui pendidikan. Tantangan pendidikan dalam mempersiapkan hal tersebut diantaranya yaitu bagaimana menciptakan sumberdaya berkualitas yang mampu ikut membangun tatanan sosial dan ekonomi melalui pengembangan kurikulum yang sesuai dengan tuntutan kompetensi abad 21. Diharapkan melalui penerapan dan pengembangan rancangan strategi-strategi pendidikan abad 21, pendidik dan peserta didik memiliki kecakapan, keterampilan, dan kompetensi abad 21 yang mencakup: communication, collaboration, critical thingking and problem solving, creativity and innovation skill serta penguasaan TIK yang membutuhkan keterampilan berpikir tingkat tinggi atau Higher Order Thinking Skill (HOTS) sehingga dapat tercipta masyarakat yang terdidik di masa depan yaitu mampu menghadapi tantangan zaman yang semakin kompetitif sehingga dapat meningkatkan daya saing bangsa.

Berdasarkan hal tersebut, maka perlu dikaji lebih jauh lagi terkait pengembangan kurikulum di Indonesia menghadapi tuntutan kompetensi abad ke-21 yang akan dibahas dalam makalah ini.

\section{B. Pembahasan}

\section{Teori}

1. Karakteristik Pendidikan dan Tuntutan Kompetensi Abad 21

Kecakapan pengetahuan, keterampilan dan sikap, serta penguasaan terhadap teknologi menjadi bagian yang terintegrasi dalam pendidikan abad 21. Kecakapan tersebut membutuhkan keterampilan berfikir tingkat tinggi atau Higher Order Thinking Skills (HOTS) yang dapat dikembangkan dengan

2 Peraturan Menteri Pendidikan Nasional No. 16 Tahun 2007. 
mempertimbangkan karakteristik kompetensi dan materi pembelajaran melalui berbagai model pembelajaran berbasis aktifitas. ${ }^{3}$

Kecenderungan abad 21 memiliki perbedaan yang kontras dengan abad sebelumnya, diantaranya yaitu bahwa pendidikan abad 20 yang masih menggunakan LOTS (Lower Order Thinking Skills) atau keterampilan berpikir tingkat rendah yang mencakup "mengingat, memahami dan mengamalkan” menjadi hal yang perlu ditingkatkan di abad 21. LOTS tidak dapat dijadikan sebagai satu-satunya instrumen dalam meningkatkan sumber daya manusia, akan tetapi dapat dijadikan dasar dalam menggapai pengetahuan. LOTS hanya terbatas pada kemampuan menghapal, dan memahami sehingga tidak bisa membentuk SDM yang mampu mencipatkan sebuah produk yang menjadi hasil dari ilmu pengetahuannya. ${ }^{4}$

Salah satu bagian terpenting dalam pendidikan di abad 21 yaitu meningkatkan LOTS menjadi HOTS (Higher Order Thinking Skills) atau keterampilan berpikir tingkat tinggi. Keterampilan ini meliputi "menganalisis-mengevaluasi dan mencipta” yang dapat dilalui dengan melanjutan keterampilan pada LOTS. Tiga kata inilah yang seharusnya dipraktikan di ruang kelas guru-guru masa kini. ${ }^{5}$

Analogi yang sering digunakan untuk menggambarkan proses LOTS adalah anak yang diberi ikan dan anak yang diberi kail maka kemudian anak yang mana yang bisa bertahan hidup lebih baik, apakah yang langsung diberi ikan atau diberi kail. Maka jawabannya adalah anak yang kedua. Anak akan belajar lebih banyak hal ketika diberi kail, bukan hanya menangkap dan memakan ikan, tapi juga berlatih bagaimana memecahkan masalah tentang umpan, tentang kolam, atau pelajaran lain sebagai pembelajaran dalam kehidupan. Hal itulah yang membedakan abad 20 dan $21 .{ }^{6}$

${ }^{3}$ Syarifuddin K., Inovasi Kurikulum 2013 : Pendidikan Agama Islam Dan Budi Pekerti (Yogyakarta: Deepublish, 2018), 197.

${ }^{4}$ Zaki Mubarak, Problematika Pendidikan Kita: Masalah-Masalah Pendidikan Faktual Dari Guru, Desain Sekolah Dan Dampaknya (Depok: Ganding Pustaka Depok, 2019), 19.

5 Mubarak, 19.

${ }^{6}$ Mubarak, 20. 
Kemajuan dan tuntutan abad 21 menghendaki pendidikan melakukan penyesuaian di segala aspek, termasuk pada kurikulum. Salah satu tuntutan pengembangan kurikulum abad 21 di sekolah yaitu mengubah pendekatan pembelajaran menjadi berpusat pada peserta didik dari pembelajaran yang sebelumnya berpusat pada pendidik. Hal tersebut sesuai dengan kecakapan berpikir dan belajar (thinking and learning skils) yang harus dimiliki anak sebagai tuntutan dunia masa depan sebagaimana yang termuat dalam kerangka kerja pembelajaran inovatif abad 21 yang dicetuskan oleh Partnership for 21st Century Learning (2011). ${ }^{7}$

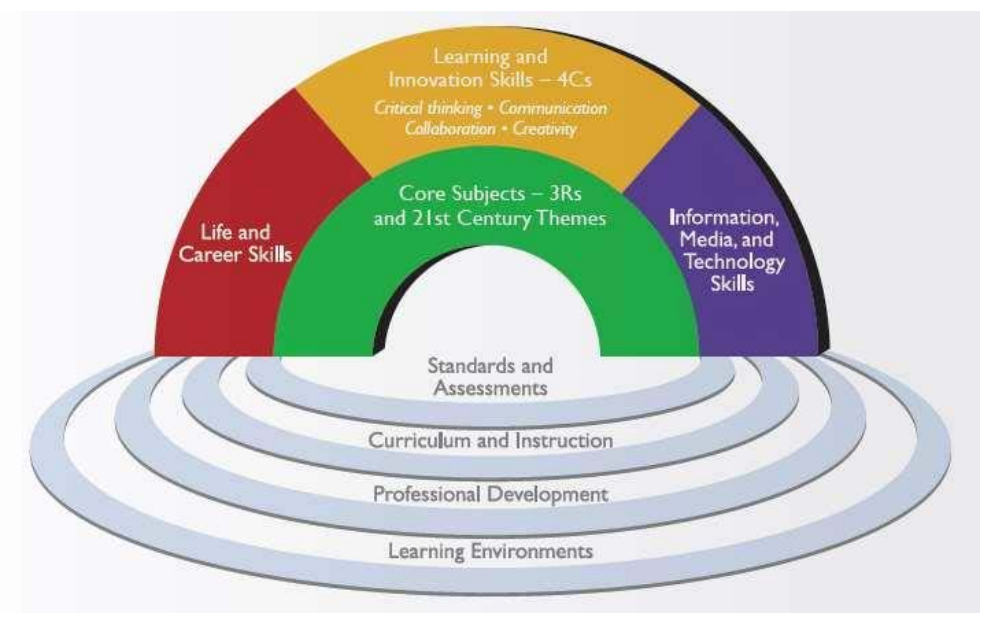

Gambar 1. Kerangka Kerja Pembelajaran Abad 21

Dari Gambar kerangka kerja tersebut menunjukkan bahwa konsep pengembangan pembelajaran abad 21 tidak cukup pada aspek pengetahuan saja, sehingga perlu dilengkapi dengan keterampilan-keterampilan sebagai berikut.

a. Pembelajaran dan keterampilan inovatif seperti berpikir kritis dan pemecahan masalah, kreativitas dan inovasi, komunikasi, dan kolaborasi.

b. Keterampilan hidup dan karir meliputi kemampuan dalam hal fleksibilitas dan adaptif, berinisiatif dan mandiri, keterampilan sosial dan budaya, produktif dan akuntabel, kepemimpinan dan tanggung jawab.

c. Keterampilan informasi, media dan teknologi artinya peserta didik harus peka terhadap informasi, media, dan TIK.

7 P21 (Partnership for 21st Century Skills), “Framework for 21st Century Learning” 
Berdasarkan hal tersebut, pemerintah terus berupaya meningkatkan kualitas pendidikan di Indonesia dengan menjadikan framework for 21st century learning sebagai landasan dalam pengembangan pendidikannya, diantaranya yaitu: pengembangan standar pendidikan nasional, peninjauan dan revisi kurikulum secara berkala dan berkelanjutan, pengembangan kemampuan profesional bagi SDM, serta pengembangan lingkungan pembelajaran yang merujuk pada framework for 21st century learning.

Kemampuan pendidik dalam mengembangkan rencana pembelajaran merupakan hal yang sangat menentukan peserta didik untuk memiliki semua kecakapan tersebut. Kegiatan-kegiatan yang menantang peserta didik untuk berpikir kritis dalam memecahkan masalah, mendorong untuk bekerja sama dan berkomunikasi menjadi hal penting yang harus termuat dalam rencana pembelajaran yang dibuat. ${ }^{8}$

\section{Metode}

Jenis metode yang digunakan dalam penelitian ini adalah studi kepustakaan atau library research. Metode ini membatasi kegiatannya hanya pada memanfaatkan sumber kepustakaan untuk memperoleh data penelitiannya, tanpa melakukan riset lapangan. ${ }^{9}$ Peneliti berusaha mengumpulkan data pustaka, membaca, mencatat, serta mengolah berbagai informasi tentang pengembangan kurikulum di Indonesia menghadapi tuntutan kompetensi abad ke-21 melalui berbagai sumber terkait.

\section{Hasil dan Pembahasan}

A. Pengembangan Kurikulum Di Indonesia Menghadapi Tuntutan Kompetensi Abad Ke-21

Pada abad ke 21, sumberdaya manusia dituntut untuk terus meningkatkan kualitasnya, salah satunya yaitu melalui lembaga-lembaga

(http://www.21stcenturyskills.org, 2011).

8 Hamid Darmadi, Pengantar Pendidikan Era Globalisasi (Banten: An1mage, 2019), 118.

9 Iwan Hermawan, Metodologi Penelitian Pendidikan: Kuantitatif, Kualitatif, Dan 
yang dikelola secara profesional. Tuntutan-tuntutan abad 21 yang serba baru merupakan tantangan bagi manusia untuk melakukan terobosan dalam berpikir dan penyesuaian konsep dan tindakan-tindakan. ${ }^{10}$

Dalam pengembangan kurikulum abad 21 ini hendaknya juga mempertimbangkan persperektif global bukan hanya nasional ataupun lokal. Kurikulum harus mampu membawa siswa untuk berpikir global dalam arti siswa mampu mengungkapkan keluasan informasi yang dapat digunakan sebagai pegangan untuk mengarahkan mereka menjadi warga negara yang produktif dan menjadi insan yang mempunyai kepedulian sosial terhadap orang lain di sekitarnya, mampu bekerja sama, serta saling ketergantungan secara harmonis. ${ }^{11}$

Berdasarkan hal tersebut, sebagai upaya pemecahan masalah pendidikan dalam menjawab tantangan abad 21, perlu dikaji beberapa kemungkinan konsep kurikulum yang bisa diterapkan di sekolah, khususnya masalah pengembangan kurikulum seperti apa yang lebih cocok diterapkan di era sekarang dan masa depan.

1. Kurikulum berbasis kompetensi dan karakter

Sebagai kunci memasuki abad ke-21, UNESCO menetapkan pentingnya belajar sepanjang hayat yang tertuang dalam empat pilar pendidikan yang diajukan sebagai dasar-dasar dari pendidikan (the foundation of education). ${ }^{12}$ Keempat pilar tersebut yaitu: ${ }^{13}$

a. Learning to know (berorientasi pada pengetahuan logis dan rasional)

Pilar dasar ini merupakan kunci penidikan dan belajar sepanjang hayat (lifelong education) dan (learning throughout life). Learning to know berarti belajar untuk memperoleh pengetahuan dan untuk melakukan

Mixed Methode (Kuningan: Hiudayatul Quran, 2019), 134-135.

10 Estetika Wijaya, Transformasi Pendidikan Abad 21 Sebagai Tuntutan Pengembangan Sumber Daya Manusia Di Era Global (Prosiding Seminar Nasional Pendidikan Matematika 1, 2016), 263.

11 Suryanto, Persoalan Implementasi Kurikulum (Jakarta: Kompas, 2006), 8.

12 Ali Sudin, Kurikulium Dan Pembelajaran (Bandung: UPI Press, 2014), 97.

13 Sudin, 97-98. 
pembelajaran selanjutnya yang berarti bahwa pentingnya penguasaan materi atau pengetahuan dan menumbuhkan kemauan untuk belajar sepanjang hayat yang berarti siap untuk selalu belajar ketika menghadapi situasi baru yang memerlukan keterampilan baru.

b. Learning to do (berorientasi pada bagaimana mengatasi suatu masalah) Pilar kedua ini menuntut penguasaan kompetensi yang memungkinkan seseorang untuk dapat hidup dalam berbagai kedadaan atau situasi yang berbeda-beda, belajar bekerja sama dalam tim dan belajar menghadapi berbagai situasi yang sering tidak terduga.

c. Learning to be (berorientasi pada pembentukan karakter) Pilar ketiga ini yaitu belajar mengaktualisasikan diri sebagai individu mandiri dengan kepribadian yang memiliki tanggung jawab pribadi (personal responsibillity) untuk mencapai tujuan bersama.

d. Learning to live together (beroreantasi untuk bersikap toleran dan siap bekerja sama)

Pilar keempat merupakan pemahaman dari ketiga pilar sebelumnya yang memungkinkan terciptanya sikap apresiasi tentang orang lain, sejarah, tradisi dan nilai-nilai spiritual, kemudian menjadikan hal tersebut sebagai yang mendasari semangat baru untuk mampu mengamalkan kondisi saling memahami dan memecahkan konflik keberagaman dan perbedaan dengan cara damai.

Sementara itu, draft kurikulum 13 yang dalam kurikulum nasional dikenal sebagai kurikulum berbasis kompetensi dan karakter, telah menjadikan empat pilar tersebut sebagai rujukan utama dalam pengembangan model pembelajaran. ${ }^{14}$ Tidak hanya itu, proses pembelajaran pada kurikulum 2013 dilaksanakan menggunakan pendekatan ilmiah dengan mempertimbangkan pengembangan kecakapan pengetahuan, keterampilan dan sikap, serta penguasaan terhadap teknologi menjadi bagian yang terintegrasi dalam pendidikan abad 21 meliputi :

14 Solih Hidayat, Pengembangan Kurikulum Baru (Bandung: PT Remaja Rosdakarya, 2013), 123. 
kecakapan memecahkan masalah, berpikir kritis, kolaborasi, dan kecakapan berkomunikasi sebagai landasannya. ${ }^{15}$

Konsep pendidikan abad 21 tersebut perlu ditumbuhkan melalui budaya sekolah oleh semua yang terlibat dalam proses pendidikan baik di keluarga, sekolah maupun di masyarakat dengan mempertimbangkan akar budaya masyarakat yang menjunjung tinggi nilai-nilai agama, maka sekolah dasar di Indonesia seharusnya dikembangkan untuk membantu siswanya menguasai beberapa kompetensi berikut: ${ }^{16}$

a. Kompetensi keagamaan

Kemampuan manusia dalam memperoleh pengalaman keagamaan yang bermakna bagi kehidupan kaitannya dengan menjalankan fungsinya sebagai makhluk ciptaan Allah Swt.

b. Kompetensi akademik

Kemampuan mengikuti perkembangan ilmu pengetahuan dan teknologi yang relevan dengan usia dan tingkat perkembangan siswa kaitannya dengan konsep belajar sepanjang hayat atau pendidikan seumur hidup (life long education).

c. Kompetensi ekonomik

Kemampuan untuk dapat memenuhi kebutuhan ekonomi agar siswa dapat hidup layak di masyarakat. Bagian penting dari kompetensi ini diantaranya yaitu sikap usaha dan etos kerja yang mendukung produktivitas pribadi.

d. Kompetensi sosial pribadi

Keterampilan mengelola diri sendiri (intrapersonal) dalam kehidupan masyarakat yang heterogen kaitanya dengan kemampuan untuk dapat hidup adaptif sebagai warga negara dan warga masayarakat internasional yang demokratis.

15 Daryanto and Syaiful Karim, Pembelajaran Abad 21 (Yogyakarta: Gava Media, 2017), 45. 
2. Model-model pembelajaran abad 21

Berbagai sendi kehidupan diantaranya yaitu gaya hidup manusia, baik dalam bekerja, bersosialisasi, bermain maupun belajar, tidak terkecuali di bidang pendidikan telah mengalami perubahan sebagai imbas dari pesatnya kemajuan teknologi informasi dan komunikasi. ${ }^{17}$

Berkenaan dengan prinsip-prinsip pokok pembelajaran abad 21 Jennifer Nichols merumuskan empat langkah implementasi pendidikan dan pembelajaran yang dapat dijelaskan sebagai berikut: ${ }^{18}$

a. Education should be collaborative (Pendidikan harus berkolaborasi).

Salah satu realitas pendidikan yang turut melatarbelakangi perubahan kecakapan abad 21 yaitu praktik pendidikan yang masih cenderung membentuk orientasi belajar kompetisi yaitu output yang dihasilkan adalah suka bersaing tapi lupa kerjasama dan kolaborasi, terlihat dari masih berlakunya perangkingan akademik, kelas akselerasi, dan sekolah-sekolah unggulan atau favorit. Hal tersebut kontra dengan tuntutan kompetensi abad 21 yang menghendaki outputnya memiliki kecakapan berkolaborasi sebagai implikasi dari perubahan pesat teknologi dan informasi yang menuntut kemampuan adaptasi yang cepat dalam merespon setiap perubahan. ${ }^{19}$

Perbedaan latar budaya dan nilai-nilai yang dianut masing-masing orang berimplikasi pada pentingnya pendidikan dalam menumbuhkan kemampuan peserta didik agar dapat berkolaborasi dengan orang lain, menghargai kelebihan dan kekurangan setiap orang serta mengambil peran dan menyesuaikan diri secara tepat dengan orang lain. Begitu juga sekolah, terutama guru hendaknya dapat bekerja sama dengan lembaga pendidikan atau guru lainnya di berbagai belahan dunia untuk saling berbagi informasi dan pengalaman tentang praktik dan metode pembelajaran yang telah dikembangkan sehingga dapat

16 Sudin, Kurikulium Dan Pembelajaran, 98-100.

17 Darmadi, Pengantar Pendidikan Era Globalisasi, 114.

18 Karim, Pembelajaran Abad 21, 9-11.

19 Rayindra Dwi Prayogi and Rio Estetika, “Kecakapan Abad 21: Kompetensi Digital 
dijadikan pertimbangan dalam proses pembelajaran yang lebih baik.

b. Learning should have context (Belajar harus memiliki konteks)

Pentingnya mengaitkan materi pembelajaran dengan kehidupan sehari-hari siswa sehingga pembelajaran menjadi berarti yaitu memberikan dampak terhadap kehidupan siswa baik di sekolah maupun di luar sekolah. Siswa dibantu untuk dapat menemukan nilai, makna dan keyakinan atas apa yang sedang dipelajarinya sehingga dapat menerapkan dalam kehidupan sehari-harinya melalui berbagai metode pembelajaran yang memungkinkan siswa terhubung dengan dunia nyata (real world).

c. Instruction should be student-centered (Pembelajaran berpusat pada siswa)

Pentingnya menggunakan pendekatan pembelajaran yang berpusat pada siswa dalam proses pembelajaran yaitu memposisikan siswa sebagai subyek pembelajaran yang memiliki minat dan potensi untuk dikembangkan secara aktif. Fokus pembelajaran bukan lagi hanya ditekankan pada mendengarkan dan menghafal materi pelajaran yang diberikan, tetapi lebih dari itu yaitu bagaimana menumbuhkan kemampuan siswa dalam mengkonstruk pengetahuan dan keterampilannya sesuai dengan kapasitas dan tingkat perkembangan berfikirnya, sambil diajak berkontribusi untuk memecahkan masalah-masalah nyata yang terjadi di masyarakat.

Dalam hal ini, bukan berarti kontrol belajar diserahkan kepada siswa sepenuhnya, siswa masih tetap memerlukan peran guru sebagai fasilitator dan pembimbing yang berupaya membantu siswa ketika mengalami hambatan dalam proses pembelajaran.

d. Schools should be integrated with society (Sekolah harus diintegrasikan dengan masyarakat).

Pentingnya mempersiapkan peserta didik untuk dapat menjadi warga negara yang bertanggung jawab, memiliki kepekaan dan empati

Pendidik Masa Depan,” Jurnal Manajemen Pendidikan 14, no. 2 (2019), 144. 
serta kepedulian sosial dengan melibatkan peserta didik dalam berbagai kegiatan di lingkungan sosial masyarakat, seperti: program pendidikan, kesehatan, lingkungan hidup, dan lain sebagainya. Salah satu misalnya yaitu melalui pengadaan kegiatan pengabdian masyarakat dimana dapat melatih siswa belajar mengambil peran dan menyusun aktivitas tertentu dalam lingkungan sosial.

Setidaknya, terdapat dua hal yang harus dikuasai dalam merealisasikan pembelajaran berbasis kompetensi abad 21, diantaranya yaitu : pendekatan dan model pembelajaran. Dalam konteks Indonesia, hal ini telah disusun dalam kerangka kurikulum 2013 (K-13) yang didesain untuk menjawab tantangan abad 21 agar siswa dapat dipersiapkan menjadi generasi emas Indonesia 2045. ${ }^{20}$

Diantara pendekatan yang ditawarkan, setidaknya terdapat dua pendekatan pokok dalam pembelajaran K-13 yang erat kaitannya dengan kebutuhan abad 21, yaitu pendekatan inkuiri dan ilmiah. ${ }^{21}$

a. Pendekatan inkuiri

Pendekatan inkuiri adalah pendekatan yang menekankan siswa tidak hanya diberi tahu namun mencari tahu. Dalam tujuan pembelajarannya, sikap atau keterampilan siswa dalam proses mendapatkan pengetahuan menjadi penting dalam pendekatan ini, disamping konsep pengetahuan.

b. Pendekatan ilmiah (Scientific Approach)

Pendekatan saintifik adalah pendekatan yang digunakan oleh para ilmuwan untuk mengkritisi atau menguji sebuah fenomena dengan tujuan menciptakan sebuah entitas atau temuan baru. Melalui penerapan pendekatan ini, diharapkan siswa dapat menciptakan produk atau berinovasi seperti para ilmuwan.

Secara bertahap, terdapat lima langkah dalam implementasi pendekatan saintifik yang di Indonesia sendiri dikenal dengan istilah

20 Mubarak, Problematika Pendidikan Kita: Masalah-Masalah Pendidikan Faktual Dari Guru, Desain Sekolah Dan Dampaknya, 25. 
5M sedangkan dalam istilah bahasa Inggris dikenal dengan 5-ing. Kelima langkah tersebut adalah mengamati (observing), menanya, (questioning), mencoba (expementing), menalar (associating), mengkomunikasikan (communicating). ${ }^{22}$ Lima langkah tersebut sangat erat kaitannya dengan desain ilmu sains (IPA) yang sangat ilmiah dan positivistik. Namun demikian, dalam implementasinya dapat juga dikolaborasikan dengan pendekatan pembelajaran sosial dan humaniora. 5M tersebut bisa dimodifikasi dan disesuaikan dengan karakteristik mata pelajaran yang berbeda dengan pertimbangan bahwa yang paling penting adalah bagaimana guru menumbuhkan produktifitas siswa.

Penguasaan guru terhadap dua pendekatan ini akan mampu meredesain pendidikan di Indonesia yang sudah terlanjur akut dalam pendekatan content based yaitu pendekatan ekspositori di mana guru menyuapi anak didik secara reseptif. Model pembelajaran dengan pendekatan inkuiri dan saintifik dapat direalisasikan dalam paling tidak empat model pembelajaran, yaitu: (1) inquiry discovery learning yaitu pembelajaran yang memberikan kesempatan kepada siswa untuk mencari tahu tentang tema yang telah ditentukan secara mandiri, (2) problem based learning yaitu pembelajaran yang terfokus pada proses menyelesaikan masalah, (3) project based learning yaitu pembelajaran yang terfokus pada pembuatan sebuah projek, (4) cooperative learning yaitu pembelajaran yang memberikan kesempatan kepada siswa untuk dapat bekerja sama dalam tim. Model pembelajaran tersebut bukan model yang kaku, namun bersifat terbuka dan dapat dimodifikasi sesuai dengan kebutuhan guru, siswa dan karakteristik materi pelajaran. ${ }^{23}$

21 Mubarak, 26.

22 Yusuf Andrian and Rusman, "Implementasi Pembelajaran Abad 21 Dalam Kurikulum 2013,” Jurnal Penelitian Ilmu Pendidikan 12, no. 1 (2019), 15.

23 Muhali, "Pembelajaran Inovatif Abad Ke-21," Jurnal Penelitian Dan Pengkajian Ilmu 
3. Pembelajaran berbasis teknologi

Di zaman informasi ini, pendidik dituntut untuk senantiasa mengikuti perkembangan teknologi agar mampu memberikan pendidikan yang berkualitas kepada peserta didik. Hal ini berarti pendidik di abad 21 harus memiliki kemampuan beradaptasi dengan menjadi pembelajar sepanjang hayat. Memiliki keterampilan memanfaatkan kekuatan teknologi terkait untuk pengajaran yang efektif menjadi hal yang sangat penting bagi para pendidik agar mampu membekali kemampuan adaptif bagi siswa sebagai upaya mengantisipasi perubahan dari perkembangan teknologi. Namun demikian, para pendidik juga perlu menyadari berbagai kemungkinan efek samping negatif yang menandai setiap inovasi. ${ }^{24}$

Peralatan TIK yang biasanya disediakan oleh sekolah umum untuk pembelajaran yaitu komputer dengan keunggulan multimedia dengan komponen-komponen seperti suara, teks, animasi, gambar, dan video yang terintegrasi. Oleh karena itu, pembelajaran yang sulit diajarkan dan dipelajari melalui buku semata karena memiliki konsep pembelajaran tingkat tinggi dapat diajarkan melalui aplikasi multimedia. ${ }^{25}$

Peserta didik dapat mengggunakan perangkat Teknologi Informasi dan Komuniasi (TIK) untuk mencari, mengeksplorasi, menganalisis, mencoba dan menggali konsep dan prinsip yang termuat dalam suatu materi yang dihadapinya, sehingga dapat relatif lebih cepat membangun struktur pemahamannya serta dapat saling bertukar informasi secara kreatif namun bertanggungjawab. ${ }^{26}$

Berdasarkan hal tersebut, dengan melakukan pembelajaran menggunakan perangkat TI (multimedia) maka pengaturan diri peserta didik dalam belajar seperti sikap inisiatif dan kemampuan belajar mandiri peserta didik dapat ditingkatkan. Penggunaan TIK yang tepat dan bijaksana, tidak hanya dapat mengembangkan kreativitas, memperluas

Pendidikan: E-Saintika 3, no. 2 (2019), 42-44.

24 Karim, Pembelajaran Abad 21, 78.

25 Karim, 79.

26 Karim, 80. 
kebebasan, dan memungkinkan fleksibilitas bagi guru dan peserta didik, tetapi yang lebih penting lagi adalah merubah dimensi proses belajar mengajar.

Terdapat tiga hal yang harus diwujudkan untuk memperbaiki mutu pembelajaran melalui pemanfaatan TIK, diantaranya yaitu : (1) baik pendidik maupun peserta didik harus memiliki akses kepada teknologi digital dan internet baik di dalam kelas, sekolah, lembaga pendidikan, dll, (2) tersedianya materi yang berkualitas dan (3) untuk membantu peserta didik agar mencapai standar akademik, dibutuhkan pengetahuan dan keterampilan dalam menggunakan alat-alat dan sumber-sumber digital yang harus dimiliki oleh pendidik. ${ }^{27}$

4. Pembelajaran berbasis E-Learning

E-learning adalah sebuah proses pembelajaran berbasis elektronik dimana salah satu media yang digunakan adalah jaringan komputer yang lebih luas atau yang biasa dikenal dengan internet. ${ }^{28}$ Bahan belajar dan tugas yang harus dikerjakan oleh peserta didik dapat ditempatkan oleh pendidik dalam web tertentu untuk diakses oleh para peserta didik sehingga dikenal dengan istilah web base learning. Keseluruhan fasilitas yang terdapat didalamnya bertujuan untuk mempermudah proses pembelajaran dan interaksi antara guru dan peserta didik. Hal ini memungkinkan berkembangnya fleksibilitas belajar yang tinggi pada peserta didik, karena peseta didik dapat mengakses bahan belajar setiap saat. ${ }^{29}$

Penerapan e-learning sebagai sebuah alternatif metode pembelajaran berbasis teknologi memiliki beberapa manfaat, yaitu: ${ }^{30}$

a. Pembelajaran dapat dilaksanakan dimana, darimana dan kapan saja (time and place flexibility)

b. Menjangkau peserta didik dalam cakupan yang luas (global audience)

27 Karim, 81.

${ }^{28}$ Karim, 107.

29 Karim, 109.

30 Karim, 108. 
c. Mempermudah penyempurnaan dan penyimpanan materi pembelajaran (easy updating of content as well as archievable capacilities)

d. E-learning mempermudah interaksi antara peserta didik dengan bahan/materi pelajaran, dengan guru maupun antara sesama peserta didik. Peserta didik dapat saling berbagi informasi atau pendapat mengenai berbagai hal (interactivity encanchement)

Selain memberikan manfaat, keuntungan e-learning diantaranya yaitu: ${ }^{31}$

a. Menghemat waktu proses belajar mengajar

b. Menghemat biaya perjalanan, infrastruktur, peralatan, buku-buku dsb

c. Mengikuti perkembangan-perkembangan terakhir (up to date)

d. Bahan bisa dipilih sesuai kebutuhan

e. Menjangkau wilayah geografis yang lebih luas karena bersifat universal

f. Siapapun di seluruh dunia dapat mengakses e-learning kapan dan dimana saja secara bersamaan dan

g. Melatih pembelajar lebih mandiri dalam mendapatkan ilmu pengetahuan

Namun demikian, terdapat berbagai kekurangan dari pemanfaatan internet untuk pembelajaran atau e-learning diantaranya yaitu: tidak semua tempat tersedia fasilitas internet, masih kurangnya keterampilan dalam penguasaan mengoperasikan internet dan bahasa pemrograman komputer, interaksi sosial yang tidak secara langsung berimplikasi pada memperlambat pembentukan value dalam proses pembelajaran. ${ }^{32}$

5. Penilaian dalam pembelajaran abad 21

Strategi penilaian pembelajaran abad 21 mengalami pergeseran dari rancangan sistem penilaian yang sebelumnya terlalu fokus pada pengukuran kemampuan pengetauan atau kognitif siswa semata menjadi pengukuran kompetensi siswa secara kompleks yang mengakomodir kompetensi pengetahuan (kognitif), kompetensi intrapersonal (manajamen

31 Karim, 109.

32 Rusman, Model-Model Pembelajaran: Mengembangkan Profesionalisme Guru 
diri), dan kompetensi interpersonal (koordinasi dan kolaborasi). ${ }^{33}$ Dalam kurikulum 2013, hal tersebut lebih dikenal dengan penilaian autentik sebagai implikasi dari pendekatan saintifik yang memuat keterampilan berpikir tingkat tinggi (HOTS) yaitu mengukur kompetensi pengetahuan, sikap, dan keterampilan berdasarkan proses dan hasil yang berkaitan dengan pengalaman kehidupan nyata peserta didik. ${ }^{34}$

Dengan demikian, penilaian seharusnya tidak lagi sekedar untuk mengetahui pencapaian hasil belajar peserta didik tetapi juga dapat meningkatkan kemampuan peserta didik dalam proses belajar sehingga penilaian dan proses pembelajaran tidak lagi diposisikan sebagai kegiatan yang terpisah. ${ }^{35}$ Penilaian seharusnya berorientasi pada mempersiapkan peserta didik untuk memiliki kesiapan menghadapi tantangan kehidupan nyata di lingkungan global yang kompleks di masa depan. ${ }^{36}$

Berdasarkan hal tersebut, pelaksanaan penilaian seharusnya melalui tiga pendekatan, yaitu: 1) assessment of learning atau penilaian setelah proses pembelajaran selesai dilakukan meliputi berbagai ujian atau berbagai bentuk penilaian sumatif lainnya, 2) assessment for learning atau penilaian sebagai perbaikan proses pembelajaran meliputi berbagai penugasan, dan 3) assessment as learning atau penilaian yang dalam kegiatannya melibatkan peserta didik secara aktif meliputi penilaian diri (self assesment) dan penilaian antar teman (peer-assesment) yang dilaksanakan selama proses pembelajaran berlangsung. ${ }^{37}$

6. Peran dan tantangan pendidik abad 21

Sebaik apa pun kurikulum dan sistem pendidikan yang ada, tanpa didukung kualitas pendidik yang baik maka semuanya tidak akan berjalan dengan baik bahkan dapat terkendala dan terhenti. Oleh karena itu,

(Jakarta: Rajawali Pers, 2016), 352.

33 Eni Winaryati, “Penilaian Kompetensi Siswa Abad 21,” Seminar Nasional Edusaintek FMIPA UNIMUS, 2018, 5-6.

34 Karim, Pembelajaran Abad 21, 12.

35 Wiwik Setiawati and dkk, Buku Penilaian Berorientasi Higher Order Thinking Skills (Jakarta: Kemendikbud, 2019), 5.

36 Winaryati, “Penilaian Kompetensi Siswa Abad 21.”, 12.

37 Setiawati, 6. 
pendidik memiliki peran yang sangat penting dalam pengembangan kurikulum. Dalam hal ini, sebagai yang merencanakan dan menjalankan rencana pembelajaran yang telah dibuat sekaligus menilai pembelajaran yang telah dilakukan, pendidik sangat menetukan kualitas SDM yang dihasilkan melalui pendidikan di sekolah. ${ }^{38}$

Selain itu, Nasution berpendapat bahwa orang yang paling bertanggung jawab menyediakan lingkungan belajar yang nyaman dan menciptakan proses belajar yang efektif adalah pendidik. Sebagaimana pula yang diungkapkan oleh Yulianto bahwa faktor kunci yang ikut menentukan arah kualitas pendidikan sehingga tidak bisa dihilangkan begitu saja adalah pendidik. Pendidik bukan hanya mengajar tetapi juga mendidik yaitu tidak hanya berperan dalam menyampaikan ilmu tapi juga bertanggung jawab dalam pembentukan karakter siswa, mengelola kelas, mengevaluasi dan mengembangkan perangkat pembelajaran yang sesuai dengan kebutuhan belajar siswa. ${ }^{39}$

Saat ini kita telah memasuki era digital yang memasuki segala aspek kehidupan manusia, termasuk aspek pendidikan. Sumber informasi untuk belajar semakin beragam atau tidak hanya yang berasal dari guru. Hal tersebut berimplikasi pada kompetensi penting yang harus dimiliki oleh pendidik masa kini diantaranya yaitu sebagai fasilitator, motivator dan inspirator bagi peserta didiknya untuk mencari dan memanfaatkan sumber belajar melalui kemajuan teknologi digital. Selain itu, guru harus memiliki minat baca yang tinggi agar terbentuk guru yang efektif yaitu dapat membantu meningkatkan pembelajaran siswa dengan lebih baik. Peran guru yang kreatif dan inovatif sangat dibutuhkan dalam mempraktekkan strategi pembelajaran abad 21 yang dapat mengkonstruksi pengetahuan siswanya. Salah satunya yaitu melalui mengkombinasikan antara model pembelajaran dan penggunaan teknologi digital yang dapat mengembangkan daya kreativitas dan inovasi siswa. Hal tersebut berarti

38 Darmadi, Pengantar Pendidikan Era Globalisasi, 120.

39 Darmadi, Pengantar Pendidikan Era Globalisasi, 120-121. 
bahwa guru telah memiliki kemampuan adaptif secara kultural yaitu menjadikan siswa sebagai subyek belajar yang dapat berkembang dan mengaktualisasikan diri secara maksimal.

Selanjutnya, beberapa karakteristik keterampilan guru abad 21 juga dirumuskan oleh International Society for Technology in Education dimana era informasi menjadi ciri utamanya, diantaranya yaitu kemampuan guru menjadi model cara belajar dan bekerja di era digital. Penguasaan atau kemahiran pendidik pada sistem teknologi ditunjukkan dengan kemampuannya dalam mentransfer pengetahuan melalui teknologi dan adaptif terhadap perubahan terkini, ide atau gagasan dikomunikasikan secara efektif kepada semua yang berperan dalam proses pendidikan di sekolah, serta memfasilitasi penggunaan alat-alat digital terkini secara efektif untuk menganalisis, mengevaluasi proses pembelajaran serta memanfaatkan sumber informasi tersebut untuk mendukung penelitian dan pembelajaran. ${ }^{40}$

Berdasarkan hal tersebut, pendidik harus menguasai keahliannya, baik dalam disiplin ilmu pengetahuan maupun metodologi mengajarnya sebagai implikasi dari pembelajaran di abad 21 yang memiliki perbedaan dengan pembelajaran di abad sebelumnya.

\section{Kesimpulan}

Sebagaimana yang termuat dalam kerangka kerja pembelajaran inovatif abad 21 yang dicetuskan oleh Partnership for 21st Century Learning (2011), konsep pengembangan pembelajaran abad 21 tidak cukup pada aspek pengetahuan saja, sehingga perlu dilengkapi dengan keterampilan-keterampilan sebagai berikut : pertama, pembelajaran dan keterampilan inovatif seperti berpikir kritis dan pemecahan masalah, kreativitas dan inovasi, komunikasi, dan kolaborasi. Kedua, keterampilan hidup dan karir meliputi kemampuan dalam hal fleksibilitas dan adaptif, berinisiatif dan mandiri, keterampilan sosial dan budaya, produktif dan

40 Daryanto and Syaiful Karim, Pembelajaran Abad 21 (Yogyakarta: Gava Media, 2017), 4-5. 
akuntabel, kepemimpinan dan tanggung jawab. Ketiga, keterampilan informasi, media dan teknologi artinya peserta didik harus peka terhadap informasi, media, dan TIK. Berdasarkan hal tersebut, pemerintah terus berupaya meningkatkan kualitas pendidikan di Indonesia dengan menjadikan framework for 21st century learning sebagai landasan dalam pengembangan pendidikannya.

Adapun prinsip-prinsip pokok pembelajaran abad 21 diantaranya yaitu: education should be collaborative (pendidikan harus berkolaborasi), learning should have context (belajar harus memiliki konteks), instruction should be student-centered (pembelajaran berpusat pada siswa), schools should be integrated with society (sekolah harus diintegrasikan dengan masyarakat). Setidaknya terdapat dua pendekatan pokok dalam pembelajaran K-13 yang erat kaitannya dengan kebutuhan abad 21, yaitu pendekatan inkuiri dan saintifik yang dijadikan rujukan dalam pengembangan berbagai model pembelajaran inovatif abad 21.

Kemampuan pendidik dalam mengembangkan rencana pembelajaran merupakan hal yang sangat menentukan peserta didik untuk memiliki semua kecakapan abad 21. Kegiatan-kegiatan yang menantang peserta didik untuk berpikir kritis dalam memecahkan masalah, mendorong untuk bekerja sama dan berkomunikasi menjadi hal penting yang harus termuat dalam rencana pembelajaran yang dibuat. Selain itu, penilaian seharusnya tidak lagi sekedar untuk mengetahui pencapaian hasil belajar peserta didik tetapi juga dapat meningkatkan kemampuan peserta didik dalam proses belajar sehingga penilaian dan proses pembelajaran tidak lagi diposisikan sebagai kegiatan yang terpisah. Penilaian seharusnya berorientasi pada mempersiapkan peserta didik untuk memiliki kesiapan menghadapi tantangan kehidupan nyata di lingkungan global yang kompleks di masa depan. Oleh karena itu, pendidik harus menguasai keahliannya, baik dalam disiplin ilmu pengetahuan maupun metodologi mengajarnya. 


\section{DAFTAR PUSTAKA}

A. Sulaeman, Pengembangan Kurikulum 2013 dalam Paradigma Pembelajaran Kontemporer, Jurnal ISLAMADINA, Volume XIV, No. 1, Maret 2015.

Andrian, Yusuf, and Rusman. "Implementasi Pembelajaran Abad 21 Dalam Kurikulum 2013.” Jurnal Penelitian Ilmu Pendidikan 12, no. 1 (2019).

Asmariani, MA "Prinsip-Prinsip Pengembangan Kurikulum Dalam Perspektif Islam”, Jurnal AL-AFKAR, Vol. III, No. II, Oktober 2014.

Darmadi, Hamid. Pengantar Pendidikan Era Globalisasi. Banten: An1mage, 2019.

Daryanto, and Syaiful Karim. Pembelajaran Abad 21. Yogyakarta: Gava Media, 2017.

Hermawan, Iwan. Metodologi Penelitian Pendidikan: Kuantitatif, Kualitatif, Dan Mixed Methode. Kuningan: Hidayatul Qur’an, 2019.

Hidayat, Solih. Pengembangan Kurikulum Baru. Bandung: PT Remaja Rosdakarya, 2013.

K., Syarifuddin. Inovasi Kurikulum 2013: Pendidikan Agama Islam Dan Budi Pekerti. Yogyakarta: Deepublish, 2018.

Mubarak, Zaki. Problematika Pendidikan Kita: Masalah-Masalah Pendidikan Faktual Dari Guru, Desain Sekolah Dan Dampaknya. Depok: Ganding Pustaka Depok, 2019.

Muhali. “Pembelajaran Inovatif Abad Ke-21.” Jurnal Penelitian Dan Pengkajian Ilmu Pendidikan: E-Saintika 3, no. 2 (2019).

P21 (Partnership for 21st Century Skills). "Framework for 21st Century Learning.” http://www.21stcenturyskills.org, 2011.

Prayogi, Rayindra Dwi, and Rio Estetika. "Kecakapan Abad 21: Kompetensi Digital Pendidik Masa Depan.” Jurnal Manajemen Pendidikan 14, no. 2 (2019).

Rusman. Model-Model Pembelajaran: Mengembangkan Profesionalisme Guru. Jakarta: Rajawali Pers, 2016.

Setiawati, Wiwik, and dkk. Buku Penilaian Berorientasi Higher Order Thinking Skills. Jakarta: Kemendikbud, 2019.

Sudin, Ali. Kurikulium Dan Pembelajaran. Bandung: UPI Press, 2014. 
Suryanto. Persoalan Implementasi Kurikulum. Jakarta: Kompas, 2006.

Syamsul Bahri, Pengembangan Kurikulum Dasar dan Tujuannya, Jurnal Ilmiah ISLAM FUTURA, Volume XI, No. 1, Agustus 2011.

Wijaya, Estetika. Transformasi Pendidikan Abad 21 Sebagai Tuntutan Pengembangan Sumber Daya Manusia Di Era Global. Prosiding Seminar Nasional Pendidikan Matematika 1, 2016.

Yunita Hariyani, Prinsip-prinsip Pengembangan Kurikulum dalam Upaya Meningkatkan Kualitas Pembelajaran, Jurnal Pendidikan Agama Islam, Vol. 2, No. 2, Juli-Desember 2018.

Yusuf, Achmad. 'Pengembangan Kurikulum PAI Berbasis Multikultural (Perspektif Psikologi Pembelajaran)'. AL MURABBI 4, no. 2 (25 May 2019): 251-74. https://doi.org/10.35891/amb.v4i2.1453. 